\title{
Integrating environmental parameters and economic benefits to analyze the ecological agriculture (EA) application in the mountain rice paddy system of Chongqing, China
}

\author{
Ying Shao ${ }^{1}$, Zhongli Chen ${ }^{2 *}$, ${ }^{*}$ Hongyan $\mathrm{Xiao}^{3}$, Zihan Zhu $^{2}$ and Bo $\mathrm{Li}^{4}$
}

\begin{abstract}
Background: Agrochemicals, such as pesticides and fertilizers used in the current conventional agriculture (CA), have contaminating effects on environments as well as food, which pose significant risks to non-target organisms and even human health. Under these environmental pressures, ecological agriculture (EA), using organic fertilizer for crop growth, was developed without pesticides to substitute CA gradually worldwide. However, EA has still not become popular in the Chinese mountain area. To identify the major factors that influence the application of EA, rice cultivation between EA and CA was compared by analyzing soil physical-chemical properties, and soil bacterial and plant diversity in Chongqing. Besides, in considering the economic benefits of small-scale paddy ecosystem, net present value (NPV) method was applied for quantification and evaluation between EA and CA.
\end{abstract}

Results: The rice yield of EA (3700 kg/ha) was significantly lower than that of CA (7500 kg/ha). Soil total nitrogen (TN, $2.24 \pm 0.16 \mathrm{~g} / \mathrm{kg}$ ) and available potassium (AK, $70.67 \pm 9.88 \mathrm{mg} / \mathrm{kg}$ ) in CA were higher than those in EA, with amounts of $1.45 \pm 0.18 \mathrm{~g} / \mathrm{kg}(T N)$ and $54.00 \pm 5.89 \mathrm{mg} / \mathrm{kg}$ (AK). Soil organic matter (SOM) of CA (55.6 $\pm 5.8 \mathrm{~g} / \mathrm{kg}$ ) was distinctly higher than that of EA $(24.4 \pm 1.43 \mathrm{~g} / \mathrm{kg})$, whereas pore water DOC concentration in EA $(71.11 \pm 7.28 \mathrm{mg} / \mathrm{L})$ was higher than that in CA (61.07 $\pm 6.61 \mathrm{mg} / \mathrm{L})$. Plant richness, bacterial diversity of ACE and Chao1 in EA were significantly higher than in $C A(P<0.05)$. The net present value (NPV) of EA was $3.72 \mathrm{CNY} / \mathrm{m}^{2}$, which was higher than that of CA (2.98 CNY/ $m^{2}$ ).

Conclusions: The relative high amounts of AP, pore water DOC and bacterial diversity revealed the improvement of soil properties by EA. Limitations on $N$ and AK may be responsible for the low yield in small-scale EA of the current study. In addition, economic benefits, plant richness and bacterial diversity suggested EA application in China as well as worldwide to facilitate the sustainable development of the agroecosystem. However, animal diversity and quantifcation on economic benefits of ecological services should be considered in further research to promote the sustainability development of the agroecosystem.

Keywords: Environmental sustainability, Ecological agriculture (EA), Paddy soil properties, Plant and soil bacterial diversity, Economic benefits

\footnotetext{
*Correspondence: zhongli.chen@cqu.edu.cn

${ }^{2}$ Key Laboratory of the Three Gorges Reservoir Eco-environment,

Chongqing University, 400045 Chongqing, People's Republic of China

Full list of author information is available at the end of the article
} 


\section{Background}

Starvation, as one of biggest challenges facing humanity, has puzzled people for thousands of years. To fight against worldwide starvation, the green revolution was developed in the late 1960s to increase agricultural production by adoption of new technologies [1]. Agrochemicals including chemical fertilizers and pesticides, as one of the main technology transfer initiatives in the green revolution, were combined with modernization management techniques in conventional agriculture (CA) and saved more than one billion people from starvation during this period [2]. However, with these CA initiatives there has been a focus on agrochemical pollution in recent years, with the improvement of public environmental awareness [3]. Data from Tillman et al. showed that the world pesticide consumption increased nearly three times from 1960 to 1990 [4], and the total fertilizer production in the world increased more than six times from 1961 (33.6 tons/years) to 2014 (207.98 tons/years) [5]. Utilization of such agrochemicals have contaminating effect on soil, air, surface and groundwater and food, which pose significant risks to non-target organisms ranging from microorganisms, to insects, plants, vertebrates, and even human health [6]. The US Department of Agriculture (USDA) reported that there were about 38.71 million people living in food insecure households, including more than 5 million children in 2017 [7]. Given these environmental and societal pressure, optimization or alteration of CA to reduce agrochemical contamination becomes an urgent issue for the related scientific communities, governments and publics [8].

Ecological agriculture (EA), which is farming without pesticides, was developed by using organic fertilizer to support the environmental sustainability of the farm. It is characterized by diverse products with good quality, pests and weeds controlled without environmental harmful input, improvement in soil quality and with low cost, which are of significant concern in recent years $[6$, 9]. Besides, due to the absence of pesticides and conventional fertilizer, the environmental, economic and health damages are intended to be minimized or avoided in EA, which increased the global demand for EA organic products robustly $[10,11]$. Thus, EA has been gradually substituting for CA worldwide $[6,12]$, while in China which possesses about $7 \%$ of agricultural acreage of the world, EA has still not increased, in particular in the Chinese mountain area, where the farmland is usually of small scale [13].

Globally, the main challenge for EA application is the lower yields when compared to CA. Jouzi et al. reported that the crop yield is largely dependent on field management including soil nutrient content, patterns of soil microbia, plant diversity as well as nutrient-microbial correlations [6]. Among these, soil organic matter (SOM), total nitrogen (TN), available phosphorus (AP), available potassium (AK) and slowly available potassium (SAK), as major nutrient elements for crops, play important roles during plant growth [14-16]. Nutrients dissolved in soil water are available fractions for plant uptake, and the dynamics of soil microorganism community structure and activity could affect nutrient biochemical processes and thus influence plant growth [17]. Plant diversity, such as diverse weeds in paddy ecosystem, could improve the stability of ecosystem, which facilitates the sustainable development of agriculture [18]. Besides, the economic benefit of crops, as one of the main concerns for farmers, directly influences farmers' decision on agricultural approach selection, which should be taken into consideration for analysis of the sustainability of the agriculture ecosystem [19].

To identify the major factors that influence the application of EA in China, the crop yield and economic benefits were integrated for analysis in the current study. Chongqing, as a typical mountainous area in China, was applied to compare the environmental parameters of $\mathrm{pH}$, water moisture, soil physical-chemical properties, soil bacterial and plant diversity in small-scale EA and CA. Rice, as a vital crop feeding about $65 \%$ of Chinese people, was selected as a target crop [20]. Considering that economic issue is an internal motivation for crop cultivation, the economic values of farming inputs, eco-environmental benefits and rice production were quantified and evaluated using the net present value (NPV) method [21]. To our knowledge, this study is the first one integrating environmental parameters and economic benefits to analyze small-scale EA application in the mountain area of Chongqing, which promotes understanding of the coevolution of the agroecosystem and social development for the sustainable development of agriculture.

\section{Methods \\ Site description}

The study site is in rural area and located at both sides of the river bank of the Heishuitan River, a tributary of the Jialing River in Beibei District of Chongqing, China (Fig. 1). The Heishuitan River is $65 \mathrm{~km}$ in length and the watershed area is $385 \mathrm{~km}^{2}$. It belongs to the subtropical monsoon region with a mean annual rainfall of $1163.3 \mathrm{~mm}$ and temperature of $17.5^{\circ} \mathrm{C}$. The geographic location of the study area is $30^{\circ} 1^{\prime} 6.42^{\prime \prime} \mathrm{N}-30^{\circ} 1^{\prime} 3.51^{\prime \prime} \mathrm{N}$, $106^{\circ} 39^{\prime} 26.68^{\prime \prime} \mathrm{E}-106^{\circ} 39^{\prime} 19.06^{\prime \prime} \mathrm{E}$ for EA and $30^{\circ} 1^{\prime} 8.75^{\prime \prime} \mathrm{N}-$ $30^{\circ} 1^{\prime} 14.48^{\prime \prime} \mathrm{N}, 106^{\circ} 39^{\prime} 30.85^{\prime \prime} \mathrm{E}-106^{\circ} 39^{\prime} 32.03^{\prime \prime} \mathrm{E}$ for CA, respectively. The upland area of both sites comprise nonagricultural areas. The CA site is $0.56 \mathrm{ha}\left(5600 \mathrm{~m}^{2}\right)$ and located at the right side of the riverbank, which is managed directly by the holder, and pesticide and fertilizer 


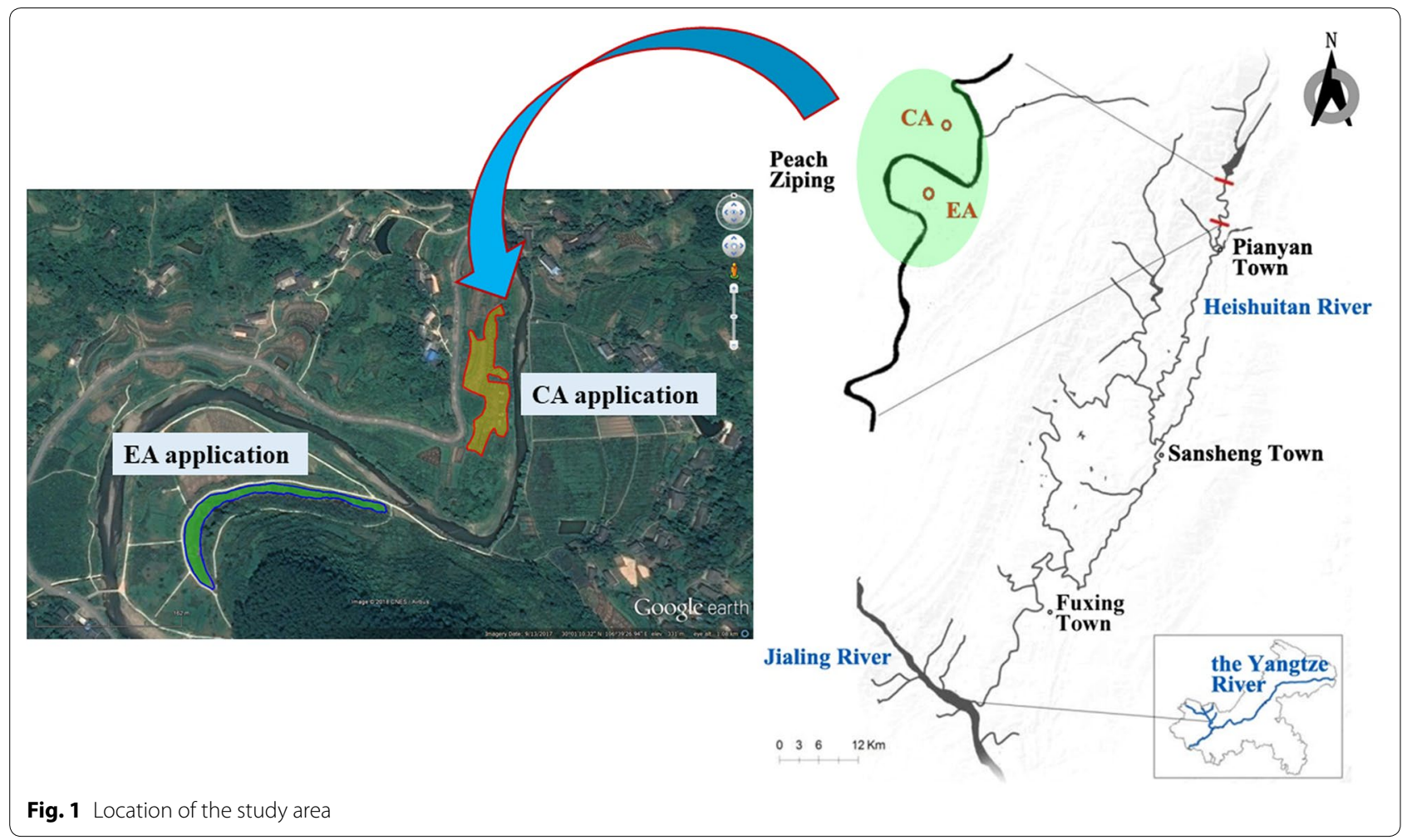

have been continually used for rice farming for more than 20 years. The site of EA is $0.42 \mathrm{ha}\left(4200 \mathrm{~m}^{2}\right)$, located at the left side of the riverbank and leased by Abao farm (a local environmental NGO), with 3 years of experience in ecological rice cultivation. The rice paddies distributed between the riverbank and EA are cultivated by the CA approach, where the altitude is lower than EA. The purpose of Abao farm is to demonstrate sustainable EA practice in this area and thus to guide farmers in altering the rice cultivation method to reduce environmental pollution and protect the ecosystems along the Heishuitan River watershed. The EA in the current study was practiced as rice-duck system [22, 23], and rapeseed meal was used as organic amendment.

\section{Field investigation and economic benefit calculation}

A survey including the fertilizer and pesticide usage, the input of labor for the rice cultivation management between EA and CA was investigated according the International Organization for Standardization (ISO) code for Yuan Renminbi (CNY) [24]. In the current study, we selected food production and biodiversity conservation as the focused ecosystem services, which were calculated into economic values [25]. The net present value (NPV) method was performed [21], given the (period, cash flow) pairs $\left(t, R_{t}\right)$ where $N$ is the total number of periods, and the time-discrete formula of the NPV is estimated as follows:

$$
\operatorname{NPV}(i, N)=\sum_{t=0}^{N} \frac{R_{t}}{(1+i)^{t}},
$$

where $t$ is the time of the cash flow, $i$ is the discount rate, i.e., the return that could be earned per unit of time on an investment with similar risk, and $R_{t}$ is the net cash flow, i.e., cash inflow-cash outflow, at time $t$. The rice is grown as an annual plant in the study area, the value of $t$ is set as 1 , and that for $i$ is set as $10 \%$ [26]. Therefore, the NPV can be calculated as NPV $=$ PV (Benefits) - PV (Costs), where PV (Benefits) are sum of rice production benefits and biodiversity conservation function benefits, while PV (Costs) are sum of cost of fertilizer and pesticide usage, labor cost and land use cost.

Field investigation was carried out on 20 August 2017 at both the CA and EA areas. As weed control in paddy fields were performed by herbicide application or in ecological ways, plant species richness and diversity were determined at the paddy bund as replacement. Plots $(1 \times 1 \mathrm{~m})$ of two types of paddies were randomly selected with six replicates each, and Patrick richness index $(S)$ [27], Simpson heterogeneity index $(D)$ [28] and ShannonWeiner index $\left(H^{\prime}\right)$ [29] were used to assess the vegetation community. Soil samples were, respectively, collected by 
a stainless steel columnar soil sampler (diameter $=7 \mathrm{~cm}$, length $=20 \mathrm{~cm}$ ) from CA and EA at $0-20 \mathrm{~cm}$ depth with three replicates each. Each replicate was obtained from a combination of triplicate sub-samples.

\section{Soil and pore water physical-chemical properties determination}

Half of the samples were prepared for soil physicalchemical characteristics analysis, and the rest of each replicate was homogeneously mixed and immediately transported under $0{ }^{\circ} \mathrm{C}$ and stored in an ultralow temperature freezer (DW-86L338, Haier, China) before microbial diversity analysis. Soil moisture was immediately determined by drying at $105{ }^{\circ} \mathrm{C}$ for $48 \mathrm{~h}$ after samples were transported to the laboratory. Prior to determining other physical-chemical parameters, the samples were air-dried, ground and sieved through a 2-mm mesh. Soil $\mathrm{pH}, \mathrm{SOM}, \mathrm{TN}, \mathrm{AP}, \mathrm{AK}$ and SAK were analyzed according to the national standards. Soil pore water (PW) was obtained via centrifugation with $6000 \mathrm{rpm}$ for $10 \mathrm{~min}$ (Sigma 3K15, Germany). The $\mathrm{pH}$ was measured by a pHmeter (Mettler Toledo FE20, Shanghai, China), and the concentrations of dissolved organic carbon (DOC) and dissolved inorganic carbon (DIC) were detected by a TOC analyzer (Shimadzu TOC-L, Japan). The concentrations of $\mathrm{NO}_{2}^{-}, \mathrm{NO}_{3}^{-}$and $\mathrm{SO}_{4}^{2-}$ in pore water were measured via an ion chromatography unit (ICS-600, Thermo Scientific, USA). The concentrations of $\mathrm{NH}_{4}{ }^{+}$and total phosphorus (TP) were measured by Nessler's reagent spectrophotometry (National Environmental Protection standards of the People's Republic of China, HJ535-2009) and ammonium molybdate spectrophotometry (National Environmental Protection standards of the People's Republic of China, HJ670-2013), respectively.

\section{Microbial diversity measurement}

Regarding soil microorganism determination, the microbial genome DNA was extracted from the soil samples $\left(0.5 \mathrm{~g}\right.$ each) using PowerSoil ${ }^{\circledR}$ DNA Isolation Kit according to the manufacturer's protocol. The V3+V4 sequenced regions of the bacterial 16s ribosomal RNA genes were amplified by PCR using primers $5^{\prime}$-ACTCCT ACGGGAGGCAGCA- $3^{\prime}$ and $5^{\prime}$-GGACTACHVGGG TWTCTAAT- $3^{\prime}$. The PCR conditions were: $95{ }^{\circ} \mathrm{C}$ for $5 \mathrm{~min}$, followed by $95{ }^{\circ} \mathrm{C}$ for $1 \mathrm{~min}, 50{ }^{\circ} \mathrm{C}$ for $1 \mathrm{~min}$, $72{ }^{\circ} \mathrm{C}$ for $1 \mathrm{~min}$, with 15 cycles of repetition, and $72{ }^{\circ} \mathrm{C}$ for $7 \mathrm{~min}$. The PCR reactions were performed in triplicate and subsequent Illumina high-throughput sequencing were conducted (Illumina HiSeq 2500). The raw tags were obtained by merging the PE reads via FLASH version 1.2.7, clean tags were achieved by filtering the raw tags through Trimmomatic version 0.33 and finally the effective tags were obtained by removing the chimera sequence using UCHIME version 4.2. Operational taxonomic units (OTUs) were clustered at the $97 \%$ similarity level using QIIME version1.8.0 and the taxonomy was noted according to Silva (Release 128, http://www.arbsilva.de).

\section{Data analysis}

Statistical analysis of OTUs richness was conducted via Good's coverage (>99\%). ACE, Chao1, Simpson and Shannon's indexes were obtained with Mothur (version 1.3). Canonical correlation analysis (CCA) was applied to determine environmental variables best explaining the assemblage's variability via Canoco (version 4.5 for Windows); forward selection was based on Monte Carlo permutation tests (permutations $=999$ ). The ordination in the $x$ - and $y$-axes and the length of the corresponding arrows indicated the importance of each physicochemical factor in explaining the taxon distribution across communities. Analysis of variance (ANOVA) was used to test the significance of results by IBM SPSS 20.0 at $P<0.05$ level.

\section{Results \\ Paddy soil and pore water physical-chemical characteristics}

As shown in Fig. 2, soil moisture was similar between CA $(73.96 \% \pm 5.05 \%)$ and $\mathrm{EA}(71.20 \% \pm 4.01 \%)$. The $\mathrm{pH}$ value of CA was $5.90 \pm 0.49$, which is slightly lower than that of EA $(7.00 \pm 0.45)$, while the SOM of CA was approximately two times greater than that of EA, amounting to $55.6 \pm 5.8 \mathrm{~g} / \mathrm{kg}$ in CA and $24.4 \pm 1.43 \mathrm{~g} / \mathrm{kg}$ in EA, respectively. Additionally, both TN and AK of CA $(2.24 \pm 0.16 \mathrm{~g} /$ $\mathrm{kg}$ and $70.67 \pm 9.88 \mathrm{mg} / \mathrm{kg}$, respectively) were higher than that of EA $(1.45 \pm 0.18 \mathrm{~g} / \mathrm{kg}$ and $54.00 \pm 5.89 \mathrm{mg} /$ $\mathrm{kg}$, respectively), and soil SAK in CA $(315.67 \pm 8.73 \mathrm{mg} /$ $\mathrm{kg})$ was also higher than in EA $(350.67 \pm 11.84 \mathrm{mg} / \mathrm{kg})$. However, AP of EA $(10.17 \pm 5.37 \mathrm{mg} / \mathrm{kg})$ was significantly higher than that of CA $(1.57 \pm 0.81 \mathrm{mg} / \mathrm{kg})$. Regarding soil pore water $(\mathrm{PW})$, the $\mathrm{pH}$ values of both $\mathrm{PW}$ were higher than those of the corresponding soils, amounting to $6.96 \pm 0.32$ and $7.77 \pm 0.06$ for CA and EA, respectively. DOC concentration of EA $(71.11 \pm 7.28 \mathrm{mg} / \mathrm{L})$ was higher than that of CA $(61.07 \pm 6.61 \mathrm{mg} / \mathrm{L})$, implying that a relatively high amount of organic compounds was transformed from solid phase to liquid phase. However, TP of both CA $(0.10 \pm 0.10 \mathrm{mg} / \mathrm{L})$ and EA $(0.34 \pm 0.22 \mathrm{mg} / \mathrm{L})$ were distinctly lower than AP in the corresponding soils.

Statistical analysis showed that significant differences were found for soil SOM $(P<0.01)$, TN $(P<0.01)$ and AK $(P<0.05)$ between $C A$ and EA. Concerning pore water, $\mathrm{pH}(P<0.05)$, DIC $(P<0.01)$ and $\mathrm{NO}_{2}^{-}(P<0.05)$ concentrations differed significantly between $\mathrm{CA}$ and $\mathrm{EA}$. 


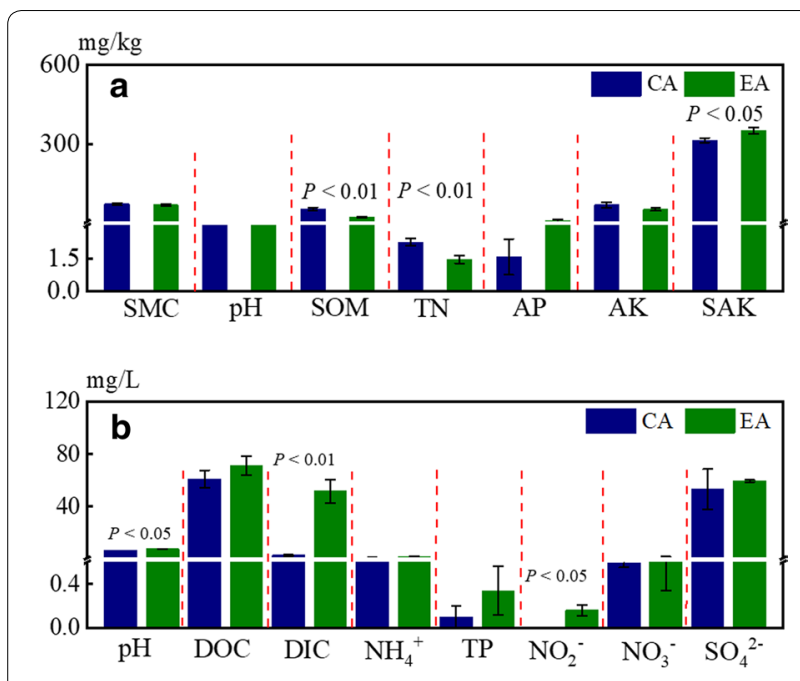

Fig. 2 Physical-chemical characteristics of rice soil (a) and its pore water (PW) (b) between CA and EA. CA conventional agriculture, $E A$ ecological agriculture, $S M C$ soil moisture content, $T N$ soil total nitrogen, SOM soil organic matter, AP soil available phosphorus, AK available potassium, SAK slowly available potassium, $P W_{-} D O C$ pore water dissolved organic carbon, $P W \_D / C$ pore water dissolved inorganic carbon, $P W_{-} \mathrm{SO}_{4}^{2-}$ pore water sulfate, $P \mathrm{PW}_{-} \mathrm{NO}_{3}^{-}$pore water nitrate, $P W \_N O_{2}^{-}$pore water nitrite, $P W_{-} N_{4}^{+}$pore water ammonium, PW_TP pore water total phosphorus

\section{Plant and paddy soil bacterial diversities}

Plant richness in EA bund was found higher than in CA distinctly $(P<0.05)$ (Fig. 3a). Similarity, Shannon and Simpson indexes of EA bund were slightly higher than that of $\mathrm{CA}$, but the variations were not significant between the sites $(P>0.05$ for both). However, plant alpha diversity of the current study was found to be significantly higher than that in the other rice paddies and wetlands of China [30]. 16S rRNA gene libraries were established from pyrosequencing of the $\mathrm{CA}$ and $\mathrm{EA}$ communities with 61,842-65,011 effective tags (average length of $420 \mathrm{bp}$ ). By performing the alignment at a uniform length of $420 \mathrm{bp}, 1791-2084$ OTUs were clustered with 97\% similarity using the Mothur 1.30 (Fig. 3b). The total numbers of OTUs were $1814 \pm 18$ (CA) and $1979 \pm 109$ (EA), which did not vary distinctly $(P>0.05)$. ACE and Chaol represent the pattern of bacterial richness, and $\mathrm{ACE}$ and Chao1 of EA were both higher than those of CA significantly $(P<0.05)$, amounting from $1901 \pm 20$ to $2088 \pm 84$ for ACE and from $1920 \pm 23$ to $2110 \pm 87$ for Chao1, respectively. The Shannon and Simpson indexes are commonly used to evaluate the abundance and evenness of species in a community, respectively. The Shannon index of the EA $(6.702 \pm 0.087)$ was higher than that of CA (6.614 \pm 0.032$)$. The coverage of both CA and EA was higher than 0.99 , revealing that most bacterial species were characterized. Overall, the bacterial diversities of EA were higher than those of CA, and ACE and Chao1 between the two tillage varied significantly at the rice mature stage $(P<0.05)$.

The bacterial sequences were affiliated with 40 phyla, among which Proteobacteria, Acidobacteria, Chloroflexi, Nitrospirae and Gemmatimonadetes were the dominant phyla and accounted for $78.70-85.76 \%$ of the total OTUs, followed by a few other minor phyla with average abundance $>1 \%$, including Actinobacteria (3.52-4.39\%), Bacteroidetes (1.83-5.39\%), Ignavibacteriae (1.57-1.77\%) and Latescibacteria (1.38-1.50\%) (Fig. 4a). Regarding
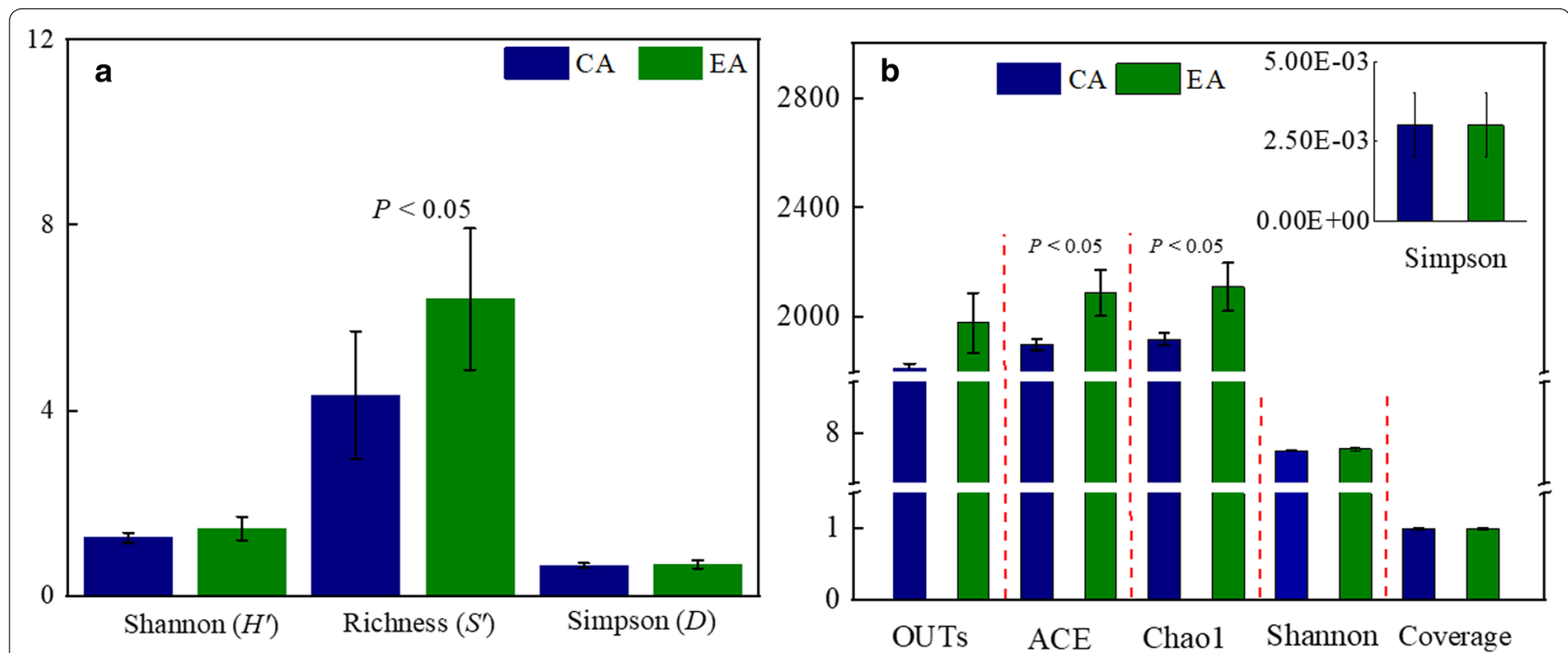

Fig. 3 Plant (a) and paddy soil (b) bacterial diversity between CA and EA. CA represents conventional agriculture, and ecological agriculture is abbreviated as EA 
the genus level, 217 genera species in total were identified. The dominant genera was Anaeromyxobacter (1.78-2.43\%), Bryobacter (0.83-1.83\%), Candidatus Solibacter (0.90-1.98\%), Desulfobacca (0.99-1.06\%), Geobacter (1.78-2.07\%), H16 (2.04-2.29\%) and Haliangium (0.78-1.69\%) (Fig. 4b). Besides, the genera with extremely minor proportion amounted to $60.68-63.18 \%$ of the total OTUs relative abundance.

CCA analysis (Fig. 5) indicated that different environmental variables may affect the bacterial distribution. Besides, some microorganisms prefer to coordinate symbiosis in rice paddy soil. The variation in bacterial composition was significantly explained by SOM, soil TN and pore water DOC, which were well correlated with the composition of the bacteria (with the longer arrow). Acidobacteria and Gemmatimonadetes were the closest to the arrow of PW_SO ${ }_{4}^{2-}$, Latescibacteria was the closest to the arrow of PW_TP, and the same was true for Chloroflexi to SMC, Proteobacteria to SAK and Nitrospirae to $\mathrm{PW} \_\mathrm{NO}_{3}^{-}$, respectively. Therefore, paddy soil bacteria are more correlated with pore water chemical properties compared to the corresponding soil.

\section{Economic benefit assessment}

As shown in Fig. 6, the cash outflow of CA was 2608 CNY $\left(0.47 \mathrm{CNY} / \mathrm{m}^{2}\right)$, among which labor input accounted for the major proportion (69\%), followed by fertilizer ( $21 \%$ in total) and pesticides $(10 \%)$ with amounts up to 1800,556 and 252 CNY, respectively.
The fertilizer application amounts were: potassium chloride $(150 \mathrm{~kg} / \mathrm{ha})$, urea $(180 \mathrm{~kg} / \mathrm{ha})$ and phosphate fertilizer $(150 \mathrm{~kg} / \mathrm{ha})$, respectively. With $\mathrm{EA}$, the cash outflow was $19,100 \mathrm{CNY}\left(4.55 \mathrm{CNY} / \mathrm{m}^{2}\right)$, which is approximately ten times as much as CA. This is because land rent (land use cost) took up 66\% of the inputs $(12,600 \mathrm{CNY})$. Besides, the proportions of labor cost and manure application were 25\% (4775 CNY) and 9\% (1719 CNY), respectively. Thus, it is found that the labor cost of EA is about 3.6 times that of CA. Regarding the cash inflow, the rice yield for CA was $7500 \mathrm{~kg} /$ ha and the average price of $\mathrm{CA}$ was about $5 \mathrm{CNY} / \mathrm{kg}$ for several years [31]; thus, the economic benefits of CA is 21,000 CNY $\left(3.75 \mathrm{CNY} / \mathrm{m}^{2}\right)$ with $\mathrm{NPV}$ amounting to $2.98 \mathrm{CNY} / \mathrm{m}^{2}$. The rice yield of EA was $3700 \mathrm{~kg} / \mathrm{ha}$, but the price is $26 \mathrm{CNY} / \mathrm{kg}$, which is five times higher than CA. The food production benefit of EA is therefore $40,404 \mathrm{CNY}\left(9.62 \mathrm{CNY} / \mathrm{m}^{2}\right)$. Additionally, the ecosystem service of biodiversity in EA is calculated to about $0.02 \mathrm{CNY} / \mathrm{m}^{2}$, with reference to the work of Meng et al. [25]. Thus, the NPV of EA is $3.72 \mathrm{CNY} / \mathrm{m}^{2}$.

\section{Discussion}

Soil physical-chemical characteristics and nutrient status

$\mathrm{SOM}$, as a major nutrient in paddy ecosystem, is mainly dependent on natural organic composition and chemical fertilizer [32]. The bioavailability of SOM is actually decided by the factions that is dissolved in the soil water [33], in particular pore water. Although SOM in

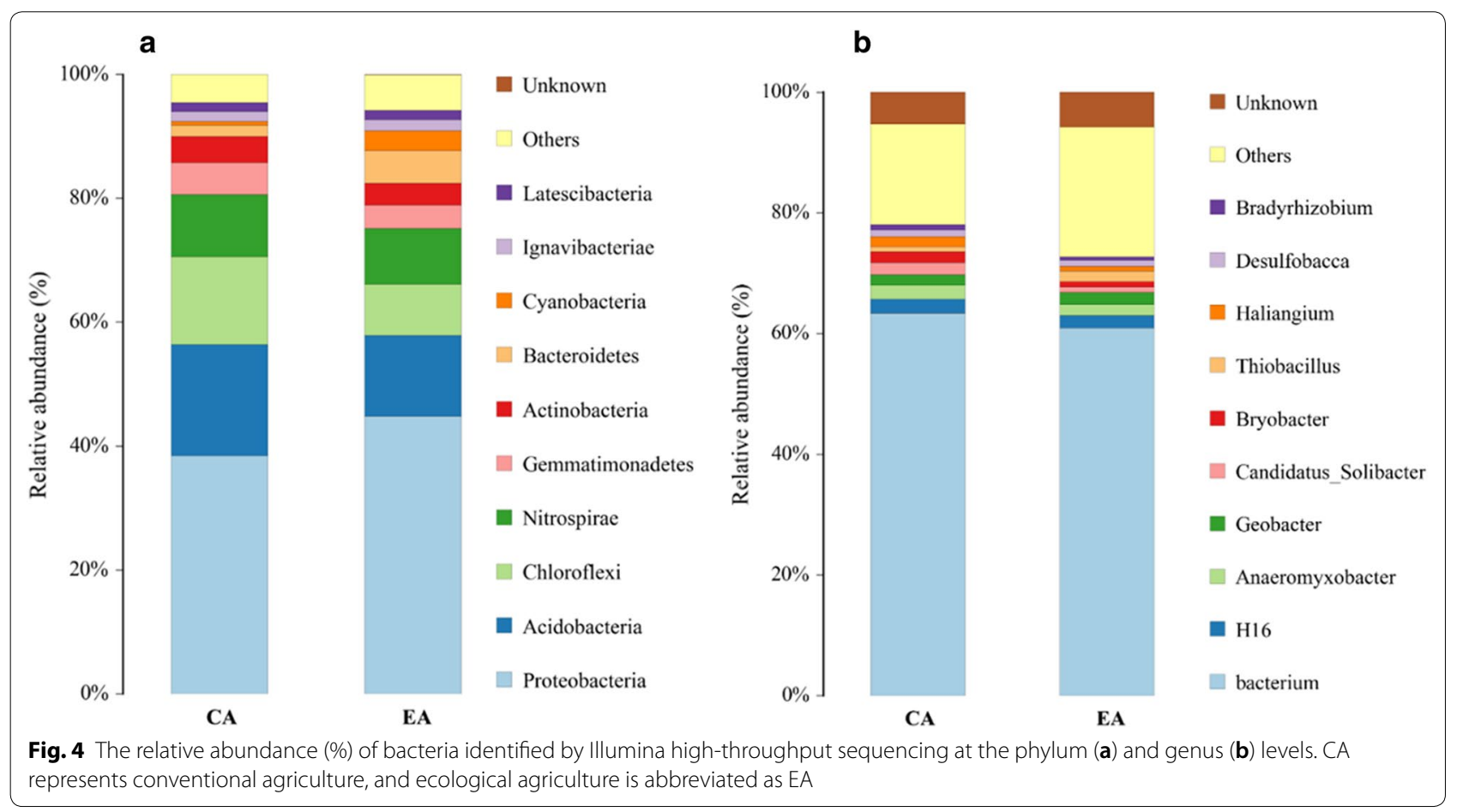




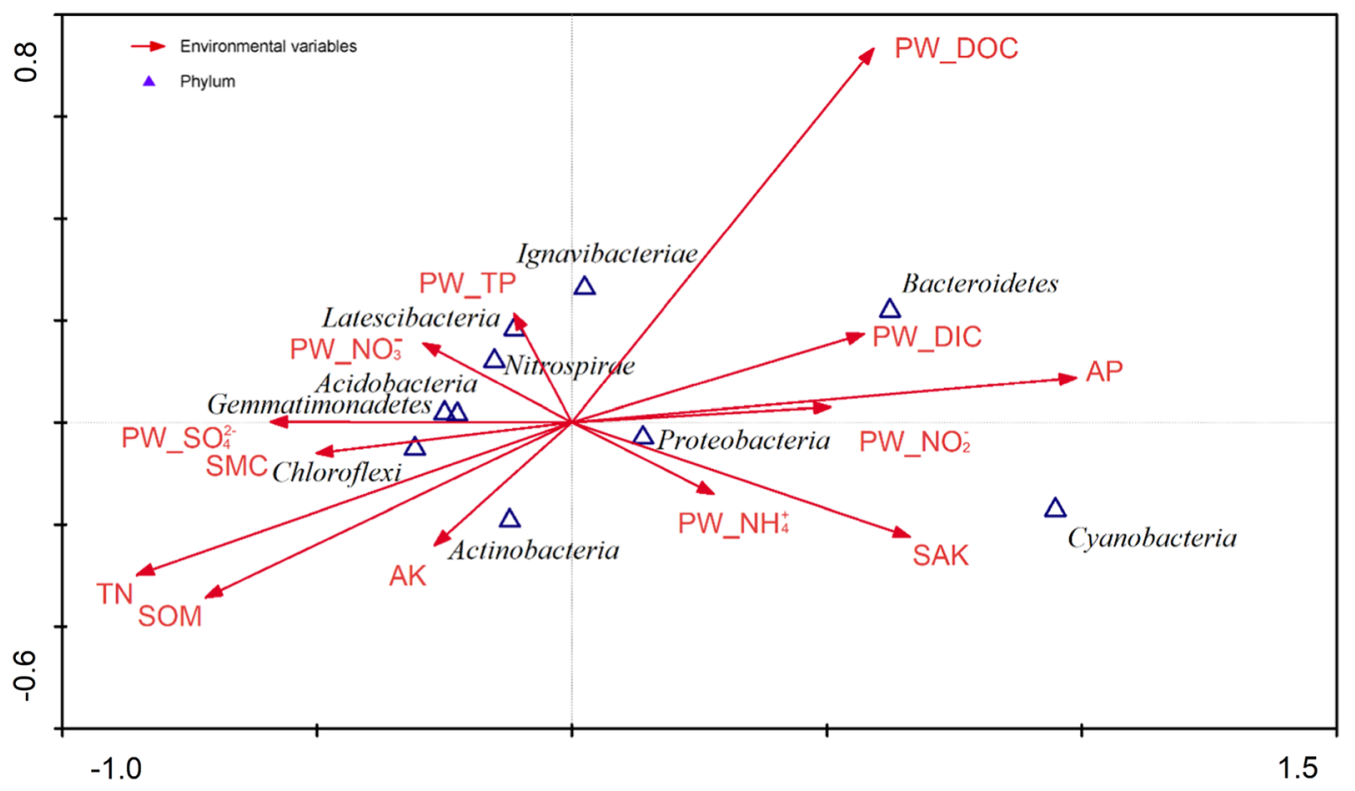

Fig. 5 Biplot of ten bacteria of relatively high abundance (in phylum level) and 13 corresponding environmental variables in CCA ordination of rice paddy soil. Biplot vectors shown represent the major explanatory environmental variables. SMC soil moisture content, TN soil total nitrogen, SOM soil organic matter, AP soil available phosphorus, AK available potassium, SAK slowly available potassium, $P W_{-} D O C$ pore water dissolved organic carbon, $P W \_D I C$ pore water dissolved inorganic carbon, $P W_{-} S_{4}^{2-}$ pore water sulfate, $P W \_N O_{3}^{-}$pore water nitrate, $P W \_N O_{2}^{-}$pore water nitrite, $P W_{-} \mathrm{NH}_{4}^{+}$pore water ammonium, $P W_{-} T P$ pore water total phosphorus

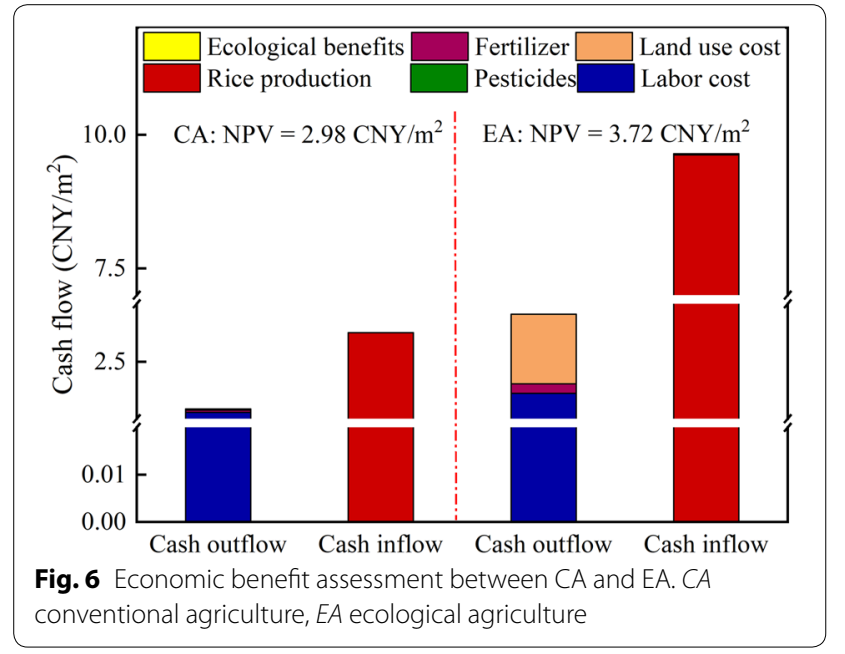

CA was significantly higher than in EA, a higher amount of pore water DOC $(71.11 \pm 7.28 \mathrm{mg} / \mathrm{L})$ found in EA implied that SOM was not the limit factor of low yield in the current study. Simultaneously, soil properties and fertility improvement by EA application has been recorded. Contrary to SOM, an extremely low amount of AP $(1.57 \pm 0.81 \mathrm{mg} / \mathrm{kg})$ was observed in CA, which is more than one-fifth of that in EA $(10.17 \pm 5.37 \mathrm{mg} / \mathrm{kg})$, showing a better condition for rice growth. Our results are similar to the study by Irshad et al., in which rapeseed meal was applied to soil resulting in accumulation of phosphorus fractions up to 4.6-fold [34]. The possible reason for this phenomenon could be that rapeseed meal was used as organic amendments in this study, since the decomposition of organic amendments usually experiences longer time, while fertilizers are accumulated by plants and microorganisms rapidly or transported to the water body in the vicinity via runoff [35]. A relatively high amounts of AP and pore water DOC were observed from EA, revealing that organic amendments can extend the sustainability of paddy ecosystem and improve paddy soil properties [36]. Soil moisture content did not vary significantly between EA and CA, both of which are favorable for rice growth. Soil $\mathrm{pH}$ at neutral level is suitable for crop growth. The $\mathrm{pH}$ in EA was $7.00 \pm 0.45$, which is higher than that in CA $(5.90 \pm 0.49)$, indicating better $\mathrm{pH}$ condition of EA than CA.

$\mathrm{Hu}$ illustrated that $\mathrm{AK}$ ranges at $50-100 \mathrm{mg} / \mathrm{kg}$ and simultaneously SAK amount is approximate or higher than $350 \mathrm{mg} / \mathrm{kg}$ are the optimal condition for rice growing [37]. Thus, soil AK $(54.00 \mathrm{mg} / \mathrm{kg}$ for EA and $70.67 \mathrm{mg} / \mathrm{kg}$ for CA) and SAK (315.67 mg/kg for CA and $350.67 \mathrm{mg} / \mathrm{kg}$ for EA) in both fields facilitated rice cultivation in the current study area. Soil TN is rich in both fields, but the available fractions for plant accumulation $(\mathrm{N}$-pore water fraction in the current study, i.e., 
$\mathrm{PW} \_\mathrm{NH}_{4}^{+}, \mathrm{PW} \_\mathrm{NO}_{2}^{-}$and $\mathrm{PW} \_\mathrm{NO}_{3}^{-}$) were the extreme limit. However, TN and AK in EA were both lower than that in $\mathrm{CA}$, indicating that limitations on $\mathrm{N}$ and $\mathrm{AK}$ may be the major reasons for the low yield in EA. Overall, EA practice fosters biotic and abiotic interactions in the soil and enhance nutrient cycling, and thus significantly improve the soil fertility, while long-term experience of CA leads to soil quality degradation [38].

\section{Biodiversity and ecological service functions}

We found that the plant richness in EA was significantly higher than in CA, implying that higher stability of paddy ecosystem in EA is expected, which promotes the sustainability of agriculture development. Although weeds have generally been considered as a main factor limiting grain yield due to the strong competition with rice plants for nutrient uptake [39], multiple ecological benefits can be obtained through optimization on weeds diversity, for instance biodiversity conservation, pest control, greenhouse effect mitigation and nutrient and soil properties' improvement $[22,23]$. The rice-duck cultivation, as one of the effective ecological approaches to control weeds and pest, contributed remarkably to the sustainability of paddy ecosystem in EA.

According to the CCA results, SOM, soil TN and pore water DOC were highly responsible to the patterns of bacterial diversity. Although the amounts of SOM and soil TN were higher in CA than in EA, pore water DOC of EA was contrarily higher than that of CA. Bacterial diversity in EA were higher than that in $\mathrm{CA}$, in particular for ACE and Chao1 $(P<0.05)$. Thus, in the current study, pore water DOC could be the main reason of increasing bacterial diversity in EA, suggesting that with 3 years experience of EA, the soil properties were improved. Our results are also consistent with those of other studies that the use of biochar or straw as organic amendments can promote soil microbial diversity [40-42].

Proteobacteria, Chloroflexi and Actinobacteria are the dominant phylum in most rice paddy fields [43], which are consistent with our findings. The predominant genus belongs to Proteobacteria, except Bryobacter and Candidatus Solibacter, both of which belong to Acidobacteria in both EA and CA. With Proteobacteria, Geobacter is a dominant genus within the family of Geobacteraceae in our study, which plays an important role in metals cycling and biogeochemical cycle of nutrients and organic pollutant degradation [44]. The relatively high abundance of Anaeromyxobacter and Geobacter in the paddy field may contribute to metal reduction such as Fe(III) and $\mathrm{As}(\mathrm{V})$, and thus the higher abundance of Geobacter and Thiobacillus found in EA may alter the emission of greenhouse gases in EA [45]. The presence of Thiobacillus and Desulfobacca as predominant genera and high concentration of $\mathrm{SO}_{4}^{2-}$ in pore water could reveal fast biogeochemical cycle of sulfur in the paddy fields of the current study sites. In addition, Desulfobacca may co-contribute to the carbon transformation process with other microorganisms, for instance methane generation and oxidation [46].

\section{Economic benefits of the small-scale paddies in the mountain area}

The economic benefits of an agricultural cultivation are evaluated from NPV; the NPV of EA in the current study is $24.8 \%$ higher than that of CA, Sharda et al. even observed that the NPV of conservation bench terrace system is 56\% higher than the conventional system [26], suggesting the advantage of EA in the mountainous area. In the current study, the cash outflow was quantified by labor cost, nutrient and pesticide application. The labor cost of EA $\left(1.14 \mathrm{CNY} / \mathrm{m}^{2}\right)$ is 3.6 times more than that of $\mathrm{CA}\left(0.32 \mathrm{CNY} / \mathrm{m}^{2}\right)$ currently, both of which will increase continually due to the labor shortage resulting from the depopulation in the mountainous rural area, implying the necessity to optimize EA practice. Although the fertilizer cost of EA $\left(0.41 \mathrm{CNY} / \mathrm{m}^{2}\right)$ is four times that in CA $(0.1$ $\mathrm{CNY} / \mathrm{m}^{2}$ ) and accounted up to only $10 \%$ of the cash outflow, soil fertility is better maintained in EA. Thus with soil degradation in CA, chemical fertilizer usages may increase. Since the land rent in EA accounted for $66 \%$ of the cost $\left(12,600 \mathrm{CNY}\right.$ or $\left.3 \mathrm{CNY} / \mathrm{m}^{2}\right)$, if the farmland is managed without rent fee as $\mathrm{CA}$, the net economic benefits of EA will significantly increase. The cash inflow was characterized as economic benefits received and ecosystem services provided, in which the rice price is the most important factor due to the fact that Chinese consumers are price sensitive in their rice purchases [31]. Meanwhile, rice price is also highly correlated to the scale of rice cultivation and sales [31, 47].

Considering that EA and CA can hardly alternate between the years, the decision for EA practice has to be carefully assessed in advance. Ecosystem services are not merchandized at the markets, which is difficult to stimulate farmers' enthusiasm. While for sustainable agriculture, there is a necessity to balance the tradeoffs among production, biodiversity conservation and other ecosystem services, as well as social awareness, as pointed out by Kirchmann and Thorvaldsson and Norton $[48,49]$, in addition, a rice price guarantee and the improvement on the added values for example tourism may help the farmer's decision on EA [47]. With the increase in environmental awareness and EA products demand, CA may be replaced gradually by EA and consequently ecosystem services functions will be restored in the future.

Ladha et al. reported that rotation between rice and dry season crops such as wheat or rapeseed is one of the 
most important agricultural systems in the world, which facilitates soil properties [50]. Integrating rice-dry season crop rotation with EA is considered as a replacement of the current CA. With respect to the depopulation and aging in the mountainous rural area, traditional agriculture systems and countryside landscape as well as rural social systems have been consistently changing. Combining EA with modern technologies for improving productivity and achieving multi-ecological benefits is the trend [51], which can synergetically develop along with agriculture, social-economic, and eco-environment benefits in Chinese mountainous area [52], as well as in the other developing countries [53].

\section{Conclusion}

The current study serves as a modest spur to raise concern on the major factors that influence the application of EA in China. To this end, the patterns of soil nutrients, soil bacterial diversity, plant diversity and economic benefits of the rice paddies cultivated by CA and EA were investigated. Limitations on $\mathrm{N}$ and $\mathrm{AK}$ could be the major reasons for the low yield in EA. Pore water DOC could be the main reason for bacterial diversity increase in EA. The relatively high amounts of AP, pore water DOC and bacterial diversity revealed that EA can extend the sustainability of the paddy ecosystem and improve paddy soil properties. Besides, significant economic benefits were achieved in EA, suggesting that EA application in China mountain area can facilitate the sustainable development of the agroecosystem. However, animal diversity, as the other important biota in the agroecosystem, should be considered in further research [54]. Quantification of the economic benefits of ecological services to stimulate farmers' enthusiasm and environmental awareness is necessary.

\begin{abstract}
Abbreviations
CA: conventional agriculture; EA: ecological agriculture; USDA: the U.S. Department of Agriculture; SOM: soil organic matter; TN: total nitrogen; AP: available phosphorus; AK: available potassium; SAK: slowly available potassium; S: Patrick richness index; D: Simpson heterogeneity index; $H^{\prime}$ : Shannon-Weiner index; PW: soil pore water; DOC: dissolved organic carbon; DIC: dissolved inorganic carbon; TP: total phosphorus; OTUs: operational taxonomic units; CCA: canonical correlation analysis; ANOVA: analysis of variance; NGO: nongovernment organization; CNY: the ISO code for Yuan Renminbi; NPV: net present value.
\end{abstract}

\section{Authors' contributions}

YS supported data interpretation and drafted the manuscript; ZLC conducted sampling, interpreted and evaluated the data and drafted the manuscript; $\mathrm{ZHZ}$ provided chemical analysis data; HYX and BL contributed to supporting the writing of the manuscript. All authors read and approved the final manuscript.

\section{Author details}

1 Key Laboratory of Biorheological Science and Technology, Ministry of Education, State and Local Joint Engineering Laboratory for Vascular Implants, Bioengineering College, Chongqing University, Chongqing 400030, China. ${ }^{2}$ Key
Laboratory of the Three Gorges Reservoir Eco-environment, Chongqing University, 400045 Chongqing, People's Republic of China. ${ }^{3}$ School of Green Intelligence Environmental, Yangtze Normal University, Fulin, Chongqing 408100, People's Republic of China. ${ }^{4}$ Faculty of Architecture and Urban Planning, Chongqing University, 400045 Chongqing, People's Republic of China.

\section{Acknowledgements}

We gratefully thank the staffs of the Abao farm for the support in sampling and social survey.

\section{Competing interests}

The authors declare that they have no competing interests.

\section{Availability of data and materials}

The datasets used and/or analyzed during the current study are available from the corresponding author on reasonable request.

\section{Consent for publication}

All authors agreed to publish the paper.

\section{Ethics approval and consent to participate} Not applicable.

\section{Funding}

This work was supported by the Fundamental Research Founds for the Central Universities (Nos. 2019CDXYCH0026 and 2018CDKYGL0008) and the Scientific Research Project Fund of Chongqing Municipal Education Commission (No. KJ1401218)

\section{Publisher's Note}

Springer Nature remains neutral with regard to jurisdictional claims in published maps and institutional affiliations.

Received: 3 January 2019 Accepted: 25 March 2019

Published online: 04 April 2019

\section{References}

1. Popp J, Pető K, Nagy J (2014) Impact of pesticide productivity on food security. In: Lichtfouse E (ed) Sustainable agriculture reviews, vol 13. Springer, Cham, pp 19-33. https://doi.org/10.1007/978-3-319-00915-5_2

2. Speight JG (2017) Chapter 4-source and types of organic pollutants. Environmental organic chemistry for engineers, pp 153-201. https://doi. org/10.1016/B978-0-12-804492-6.00004-6

3. Liu YH, Zang HD, Ge TD, Bai J, Lu SB, Zhou P, Peng PQ, Shibistova O, Zhu ZK, Wu JH, Guggenberger G (2018) Intensive fertilization (N, P, K, Ca, and S) decreases organic matter decomposition in paddy soil. Appl Soil Ecol 127:51-57. https://doi.org/10.1016/j.apsoil.2018.02.012

4. Tilman D, Cassman KG, Maston PA, Naylor R, Polasky S (2002) Agricultural sustainability and intensive production practices. Nature 418:671

5. FAO (2017) http://www.fao.org/faostat/en/\#data/RA; http://www.fao.org/ faostat/en/\#data/RF; http://www.fao.org/faostat/en/\#home

6. Jouzi Z, Azadi H, Taheri F, Zarafshani K, Gebrehiwot K, Van Passel S, Lebailly P (2017) Organic farming and small-scale farmers: main opportunities and challenges. Ecol Econ 132:144-154. https://doi.org/10.1016/j.ecole con.2016.10.016

7. Coleman-Jensen A, Rabbitt MP, Gregory CA, Singh A (2018) Household food security in the United State in 2017, ERR-256. U.S. Department of Agriculture, Economic Research Service, Washington, D.C.

8. Molina MGD, Casado GIG (2017) Agroecology and ecological intensification a discussion from a metabolic point of view. Sustainability 9:1-19

9. Seufert V, Ramankutty N, Mayerhofer T (2017) What is this thing called organic? - How organic farming is codified in regulations. Food Policy 68:10-20

10. Willer $\mathrm{H}$, Klicher $L$ (2009) The world of organic agriculture-statistics and emerging trends 2009. IFOAM, Bonn; FiBL, Frick: ITC, Genf

11. Martinez-Eixarch M, Curco A, Ibanez C (2017) Effects of agri-environmental and organic rice farming on yield and macrophyte community in 
Mediterranean paddy fields. Paddy Water Environ 15:457-468. https://doi. org/10.1007/s10333-016-0563-x

12. Lotter DW (2003) Organic agriculture. J Sustain Agric 21:59-128

13. Salvador S, Corazzin M, Piasentier E, Bovolenta S (2016) Environmental assessment of small-scale dairy farms with multi functionality in mountain areas. J Clean Prod 124:94-102. https://doi.org/10.1016/j.jclep ro.2016.03.001

14. Wang QG, Bai JH, Huang LB, Deng W, Xiao R, Zhang KJ (2011) Soil nutrient distribution in two typical paddy terrace wetlands along an elevation gradient during the fallow period. J MT Sci 8:476-483. https://doi. org/10.1007/s11629-011-1122-y

15. Zhou W, LvTF, Chen Y, Westby AP, Ren WJ (2014) Soil physicochemical and biological properties of paddy-upland rotation: a review. Sci World J. https://doi.org/10.1155/2014/856352

16. Zhu HH, Wu JS, Huang DY, Zhu QH, Liu SL, Su YR, Wei WX, Syers JK, Li $Y$ (2010) Improving fertility and productivity of a highly-weathered upland soil in subtropical China by incorporating rice straw. Plant Soil 331:427-437. https://doi.org/10.1007/s11104-009-0263-z

17. Neher DA (1999) Soil community composition and ecosystem processes. Agrofor Syst 45:159-185

18. Hole DG, Perkins AJ, Wilson JD, Alexander IH, Grice PV, Evans AD (2005) Does organic farming benefit biodiversity? Biolo Conserv 122:113-130. https://doi.org/10.1016/j.biocon.2004.07.018

19. Tiwari KR, Sitaula BK, Bajracharya RM, Borresen T (2010) Effects of soil and crop management practices on yields, income and nutrients losses from upland farming systems in the middle mountains region of Nepal. Nutr Cycl Agroecosyst 86:241-253. https://doi.org/10.1007/s10705-009-9289-0

20. Huang SW, Wang L, Liu LM, Fu Q, Zhu DF (2014) Nonchemical pest control in China rice: a review. Agron Sustain Dev 34:275-291. https://doi. org/10.1007/s13593-013-0199-9

21. Dickinson D, Balduccio L, Buysse J, Ronsse F, van Huylenbroeck G, Prins W (2015) Cost-benefit analysis of using biochar to improve cereals agricultre. GCB Bioenergy 7:850-864

22. Long P, Huang H, Liao XL, Fu ZQ, Zheng HB, Chen AW, Chen C (2013) Mechanism and capacities of reducing ecological cost through rice-duck cultivation. J Sci Food Agric 93:2881-2891. https://doi.org/10.1002/ jsfa.6223

23. Lu Y, Dai Z, Zhang X, Wei H, Manda M, Nakanishi Y, Han Z (2009) Evaluation of duck rearing in the mode of rice-duck mutualism. China Poultry $31: 45-46$

24. ISO (2015) Currency codes-ISO 4217. https://www.iso.org/iso-4217currency-codes.html

25. Meng FQ, Qiao YH, Wu WL, Smith P, Scott S (2017) Environmental impacts and production performances of organic agriculture in China: a monetary valuation. J Environ Manage 188:49-57. https://doi.org/10.1016/j. jenvman.2016.11.080

26. Sharda VN, Dogra P, Sena DR (2015) Comparative economic analysis of inter-crop based conservation bench terrace and conventional systems in a sub-humid climate of India. Resour Conserv Recy 98:30-40

27. Patrick R (1949) A proposed biological measure of stream conditions based on a survey of Conestoga Basin, Lancaster County, Penn-sylvania. Proc Acad Nat Sci Phila 101:277-341

28. Simpson EH (1949) Measurement of diversity. Nature 163:688

29. Shannon CE, Wiener WJ (1949) The mathematical theory of communication. University of Illinois Press, Urbana

30. Wei CZ, Zhang JB, Zhou LY (2011) Plant diversity in wetlands along the lower Yellow River under different types of land use. J Northeast For Univ 39:40-43

31. Xu P, Su H, Lone T (2018) Chinese consumers' willingness to pay for rice. J Agribus Dev Emerg Econ 8:256-269

32. Liu M, Ekschmitt K, Zhang B, Holzhauer SIJ, Li ZP, Zhang TL, Rauch S (2011) Effect of intensive inorganic fertilizer application on microbial properties in a paddy soil of subtropical China. Agric Sci China 10:1758-1764. https://doi.org/10.1016/S1671-2927(11)60175-2

33. Oelofse M, Markussen B, Knudsen L, Schelde K, Olesen J, Jensen L, Bruun S (2015) Do soil organic carbon levels affect potential yields and nitrogen use efficiency? an analysis of winter wheat and spring barley field trials. Eur J Agron 66:62-73. https://doi.org/10.1016/j. eja.2015.02.009

34. Irshad M, Inoue M, Khattak RA, Yamamoto S, Honna T (2008) Phosphorus and metal fractions in paddy soils under different fertilizer management. J Sustain Agric 32:255-268. https://doi. org/10.1080/104400408021708637

35. Zhao Y, He X, Huang X, Zhang Y, Shi X (2016) Increasing soil organic matter enhances inherent soil productivity while offsetting fertilization effect under a rice cropping system. Sustainability 8:1-12. https://doi. org/10.3390/su8090879

36. Yin Y, Liang CH, Xi FM, Du LY, Wang JY, Bing LF (2018) Relationship between phosphorus fractions in paddy soil and phosphorus release to runoff amended with manure. Clean-Soil Air Water 46:1700192. https://doi.org/10.1002/clen.201700192

37. Hu A (2003) Plant nutrition. China Agriculture University Press, Beijing

38. Sihi D, Dari B, Sharma DK, Pathak H, Nain L, Sharma OP (2017) Evaluation of soil health in organic vs. conventional farming of basmati rice in North India. J Plant Nutr Soil Sci 000:1-18. https://doi.org/10.1002/ jpln.201700128

39. Storkey J (2006) A functional group approach to the management of UK arable weeds to support biological diversity. Weed Res 46:513-522. https://doi.org/10.1111/j.1365-3180.2006.00528.x

40. He LL, Zhong ZK, Yang HM (2017) Effects on soil quality of biochar and straw amendment in conjunction with chemical fertilizers. J Integ Agric 16:704-712. https://doi.org/10.1016/S2095-3119(16)61420-X

41. Liu YL, Wang P, Pan GX, Crowley D, Li LQ, Zheng JW, Zhang XH, Zheng JF (2016) Functional and structural responses of bacterial and fungal communities from paddy fields following long-term rice cultivation. J Soil Sediment 16:1460-1471. https://doi.org/10.1007/s1136 8-015-1343-8

42. Iqbal MT, Joergensen RG, Knoblauch C, Lucassen R, Singh Y, Watson C, Wichern F (2016) Rice straw addition does not substantially alter microbial properties under hypersaline soil conditions. Biol Fert Soils 52:867-877. https://doi.org/10.1007/s00374-016-1126-4

43. Ahn JH, Song J, Kim BY, Kim MS, Joa JH, Weon HY (2012) Characterization of the bacterial and archaeal communities in rice field soils subjected to long-term fertilization practices. J Microbiol 50:754-765. https://doi. org/10.1007/s12275-012-2409-6

44. Yuan HY, Ding LJ, Wang N, Chen SC, Deng Y, Li XM, Zhu YG (2016) Geographic distance and amorphous iron affect the abundance and distribution of Geobacteraceae in paddy soils in China. J Soil Sediment 16:2657-2665. https://doi.org/10.1007/s11368-016-1462-x

45. Qiao JT, Li XM, Li FB (2018) Roles of different active metal-reducing bacteria in arsenic release from arsenic-contaminated paddy soil amended with biochar. J Hazard Mater 344:958-967. https://doi.org/10.1016/j. jhazmat.2017.11.025

46. Roland FAE, Darchambeau F, Morana C, Bouillon S, Borges AV (2017) Emission and oxidation of methane in a meromictic, eutrophic and temperate lake (Dendre, Belgium). Chemosphere 168:756-764. https:// doi.org/10.1016/j.chemosphere.2016.10.13819

47. Liu MC, Min QW, Yang L (2018) Rice pricing during organic conversion of the Honghe Hani rice terrace system in China. Sustainability 10:1-10. https://doi.org/10.3390/su10010183

48. Kirchmann $H$, Thorvaldsson $\mathrm{G}$ (2000) Challenging targets for future agriculture. Eur J Agron 12:145-161. https://doi.org/10.1016/S1161 $-0301(99) 00053-2$

49. Norton LR (2016) Is it time for a socio-ecological revolution in agriculture? Agric Ecosyst Environ 235:13-16. https://doi.org/10.1016/j. agee.2016.10.007

50. Ladha JK, Pathak H, Padre AT, Dawe D, Gupta RK (2003) Productivity trends in intensive rice-wheat cropping systems in Asia. Improv Product Sustain Rice-Wheat Syst 65:45-76

51. Luo YF, Fu HL, Traore SD (2014) Biodiversity conservation in rice paddies in China: toward ecological sustainability. Sustainability 6:6107-6124. https ://doi.org/10.3390/su6096107

52. Miao YX, Stewart BA, Zhang FS (2011) Long-term experiments for sustainable nutrient management in China. A review. Agron Sustain Dev 31:397-414. https://doi.org/10.1051/agro/2010034

53. García-Llorente M, Rossignoli CM, lacovo FD, Moruzzo R (2016) Social farming in the promotion of social-ecological sustainability in rural and periurban areas. Sustainability 8:1-15. https://doi.org/10.3390/su8121238

54. Zhou ZY, Huang XC, Meng L, Xie TZ, Li BP (2011) Arthropod diversity on plants at field margins of organic farming paddy rice. Chin J Ecol 30:1347-1353 